\title{
Iron molybdate thin films prepared by sputtering and their electrochemical behavior in Li batteries
}

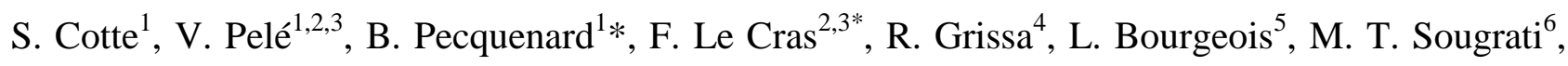 \\ H. Martinez ${ }^{4}$
}

${ }^{1}$ CNRS, Univ. Bordeaux, Bordeaux INP, ICMCB UPR 9048, 87 Avenue du Dr. Schweitzer. 33608 Pessac cedex, France

${ }^{2}$ CEA LETI, 17 rue des Martyrs, F-38054 Grenoble. France

${ }^{3}$ Université Grenoble Alpes, F-38000 Grenoble, France

${ }^{4}$ IPREM ECP - UMR CNRS 5254. Université de Pau et des Pays de 1'Adour, Hélioparc PauPyrénées, 2 Avenue du Président Angot. 64053 Pau Cedex 9, France

${ }^{5}$ Université de Bordeaux, CNRS, ISM-UMR 5255, Groupe de Spectroscopie Moléculaire, 351 Cours de la Libération, 33405 Talence cedex, France

${ }^{6}$ Institut Charles Gerhardt, UMR5253, PAC Balard, Place Eugène Bataillon, 34090 Montpellier, France

\begin{abstract}
With the aim of developing $3 \mathrm{~V}$ all-solid-state lithium microbatteries, $\mathrm{Fe}_{2}\left(\mathrm{MoO}_{4}\right)_{3}$ thin films were prepared by radiofrequency magnetron sputtering from a home-made $\mathrm{Fe}_{2}\left(\mathrm{MoO}_{4}\right)_{3}$ target using optimized sputtering conditions. In addition to elemental analyses, Mössbauer spectroscopy and XPS analyses, showing that $\mathrm{Mo}^{6+}$ and $\mathrm{Fe}^{3+}$ are the main detected species, confirmed the stoichiometric character of the films. Post-deposition annealing was necessary to form wellcrystallized thin films. The best electrochemical performance was obtained with those annealed at $500^{\circ} \mathrm{C}$ which were able to deliver a stable reversible capacity close to the theoretical one, i.e. $2 \mathrm{Li}^{+}$
\end{abstract}


per $\mathrm{Fe}_{2}\left(\mathrm{MoO}_{4}\right)_{3}$ formula unit. The corresponding voltage curve displays a plateau with a low hysteresis located at $3.0 \mathrm{~V} / \mathrm{Li}^{+} / \mathrm{Li}$ and related to the $\mathrm{Fe}_{2}\left(\mathrm{MoO}_{4}\right)_{3}-\mathrm{Li}_{2} \mathrm{Fe}_{2}\left(\mathrm{MoO}_{4}\right)_{3}$ two-phase system. Therefore, it was demonstrated for the first time the possible use of $\mathrm{Fe}_{2}\left(\mathrm{MoO}_{4}\right)_{3}$ thin films as positive electrodes for $3 \mathrm{~V}$ lithium microbatteries.

Keywords: sputtering; lithium; iron molybdate; all-solid-state batteries

Corresponding authors : Brigitte Pecquenard : E-mail: brigitte.pecquenard@ icmcb.cnrs.fr. Tel:

$+33540003303$

Frédéric Le Cras : E-mail : frederic.lecras@ @ea.fr. Tel : + 33540006638 


\section{Introduction}

The significant growth of portable electronics, generally battery-powered has induced the development of high-performance microprocessors, and systems-on-a-chips using low power consumption integrated circuits. As a consequence, these optimized devices can be powered now by miniaturized power sources such as thin film all-solid-state lithium batteries. The latter have the advantage of being manufactured by vacuum deposition techniques that are widely used in the microelectronics industry. $\mathrm{Up}$ to now, the $\mathrm{Li} / \mathrm{LiPON} / \mathrm{LiCoO}_{2}$ stack that supplies a $4 \mathrm{~V}$ voltage is the most widespread microbattery system [1]. Nevertheless, such an operating voltage is not the most suitable for many new emerging electronic devices, which often require significantly lower ones. Besides, the replacement of conventional $\mathrm{Li} / \gamma-\mathrm{MnO}_{2}$ primary batteries by thin film batteries in selected devices motivates the development of specific $3 \mathrm{~V}$ rechargeable systems [2]. Among the few possible positive thin film electrode materials able to reversibly insert/deinsert lithium around $3 \mathrm{~V}$ vs $\mathrm{Li}^{+} / \mathrm{Li}$, iron molybdate appears as a suitable candidate since it combines the following features: the ability to reversibly insert/deinsert $\mathrm{Li}$ in bulk form due to a two dimensional open framework with low volumetric change, a quite low crystallization temperature, a low material cost and environmental friendliness. In addition, this option usefully allows to achieve a $3 \mathrm{~V}$ system by changing only one step in the manufacturing process of the standard $\mathrm{LiCoO}_{2} / \mathrm{LiPON} / \mathrm{Li}$ system, i.e. the one related to the positive electrode.

The metal molybdate family has been widely studied for photoluminescence, microwave, optical fibers, scintillator, moisture sensor and catalysis applications [3-7]. Among them, iron molybdate is largely used as a catalyst for selective oxidation of methanol to formaldehyde in industrial processes [8]. This material also exhibits interesting magnetic properties, i.e. ferromagnetic structure and dominant antiferromagnetic supersuperexchange coupling along the Fe-O-O-Fe paths [9] and the ability to reversibly insert lithium ions, reported for the first time by J. B. Goodenough in the bulk material [10]. 
The crystal structure of $\mathrm{Fe}_{2}\left(\mathrm{MoO}_{4}\right)_{3}$ is indexed in a monoclinic cell ( $\mathrm{P} 2_{1} /$ a space group) at room temperature. It displays some similarities with the NASICON one and consists in corner sharing $\mathrm{FeO}_{6}$ octahedra and $\mathrm{MoO}_{4}$ tetrahedra, each oxygen atom being bound to one iron atom and one molybdenum atom [11]. Several synthesis methods were reported for the preparation of $\mathrm{Fe}_{2}\left(\mathrm{MoO}_{4}\right)_{3}$ including solid state reaction [12-13], co-precipitation [14-15], hydrothermal [16] and microwave synthesis [17].

Only few studies of the intercalation reactions in bulk $\mathrm{Fe}_{2}\left(\mathrm{MoO}_{4}\right)_{3}$ have been achieved so far. Both Delmas et al. [18] and Reiff et al. [19] have shown that lithium can be inserted electrochemically or chemically into the $\mathrm{Fe}_{2}\left(\mathrm{MoO}_{4}\right)_{3}$ framework. This induces the formation of a $\mathrm{Li}_{2} \mathrm{Fe}_{2}\left(\mathrm{MoO}_{4}\right)_{3}$ compound having the same orthorhombic symmetry (space group Pbcn) than the high temperature $\mathrm{Fe}_{2}\left(\mathrm{MoO}_{4}\right)_{3}$ phase obtained above $518^{\circ} \mathrm{C}$. During the galvanostatic reduction/oxidation (lithiation/delithiation) of the material, the voltage profile displays a well-defined plateau at $3 \mathrm{~V} v \mathrm{~s}$ $\mathrm{Li}^{+} / \mathrm{Li}$ that reveals the course of a two-phase reaction. Due to its low theoretical capacities, 91 mAh.g ${ }^{-1}$ and $326 \mathrm{mAh} . \mathrm{cm}^{-3}$, and its moderate operating voltage, $\mathrm{Fe}_{2}\left(\mathrm{MoO}_{4}\right)_{3}$ is not a suitable cathode for high energy lithium batteries. Besides, the capacity retention of the bulk material is quite limited since a fast decrease of the initial capacity over cycles is observed, even at a low current rate. This behavior has been attributed to a slow lithium insertion which originates from the nature of the two-phase reaction [18] and the poor electronic conductivity of the materials [20]. In order to overcome these limitations, the approach has consisted in shortening the ion diffusion length and electron transfer paths in the electrode by designing different nanostructures, in a similar way than for $\mathrm{LiFePO}_{4}$. Sun et al. have demonstrated the possibility to electrochemically insert $\mathrm{Na}$ ions in thin films synthesized by sputtering and to achieve a far better electrochemical performance compared to bulk material electrodes [21]: at a low current rate $(0.1 \mathrm{C})$ the specific capacity for the powder was $83 \mathrm{mAh} \cdot \mathrm{g}^{-1}$ and $25 \mathrm{mAh} \cdot \mathrm{g}^{-1}$, for the $1^{\text {st }}$ and the $30^{\text {th }}$ cycle respectively, whereas for the 
thin film it reached $94 \mathrm{mAh} \cdot \mathrm{g}^{-1}$ and $76 \mathrm{mAh} \cdot \mathrm{g}^{-1}$, for the $1^{\text {st }}$ and the $100^{\text {th }}$ respectively. A similar improvement of the electrochemical behavior was observed for $\mathrm{Fe}_{2}\left(\mathrm{MoO}_{4}\right)_{3} /$ nanosilver composite [22] and $\mathrm{Fe}_{2}\left(\mathrm{MoO}_{4}\right)_{3} /$ reduced graphene oxide composite [23-24] during Na insertion/deinsertion. In the latter case, it was demonstrated for the first time the possibility to deliver a capacity of 68 mAh.g $\mathrm{g}^{-1}$ at $5 \mathrm{C}$ and to retain $56.5 \mathrm{mAh} . \mathrm{g}^{-1}$ after 100 cycles. This excellent behavior was mainly attributed to a good conductivity of the composite electrode, high specific surface area (reduced particle size) and significantly enhanced diffusion coefficient. Now, to our knowledge, there is no report on the electrochemical behavior of $\mathrm{Fe}_{2}\left(\mathrm{MoO}_{4}\right)_{3}$ thin films towards $\mathrm{Li}$ insertion/deinsertion so far.

In the present study, radio-frequency sputtering, which is a versatile technique and a process widely used in the microelectronic industry, was used to prepare iron molybdate thin films from an inhouse $\mathrm{Fe}_{2}\left(\mathrm{MoO}_{4}\right)_{3}$ target. Sputtering conditions especially the oxygen partial pressure and the total pressure were optimized to get stoichiometric $\mathrm{Fe}_{2}\left(\mathrm{MoO}_{4}\right)_{3}$ films. Then, thorough physico-chemical and electrochemical characterizations were performed on stoichiometric films annealed at various temperatures between $200{ }^{\circ} \mathrm{C}$ and $500{ }^{\circ} \mathrm{C}$ to optimize the electrochemical performance.

\section{Material and methods}

\subsection{Preparation of a $\mathrm{Fe}_{2}\left(\mathrm{MoO}_{4}\right)_{3}$ sputtering target}

Iron molybdate was prepared by solid state reaction of $\mathrm{Fe}_{2} \mathrm{O}_{3}$ (Sigma-Aldrich, $99.0 \%$ ) and $\mathrm{MoO}_{3}$ (Sigma-Aldrich, $99.9 \%$ ) in the molar ratio 2:3. The reactants were ball-milled in an agate jar at first. The resulting mixture was then annealed at $750^{\circ} \mathrm{C}$ for $20 \mathrm{~h}$. The synthesized powder was used to prepare 2 " targets by spark plasma sintering (SPS) at $600^{\circ} \mathrm{C}$, under a pressure of $25 \mathrm{MPa}$, using a graphite die $(50.8 \mathrm{~mm})$. A dense target (compactness 91\%) was obtained and was further annealed in air at $450^{\circ} \mathrm{C}$ for $5 \mathrm{~h}$ to remove graphite traces present on its outer surface. 


\subsection{Thin films synthesis by sputtering}

All thin films were deposited by radio-frequency (RF) magnetron sputtering (PLASSYS MP450) at room temperature with no intentional heating of the substrates. Before deposition, vacuum was applied into the chamber until the pressure is less than $4.10^{-5} \mathrm{~Pa}$. Prior to each deposition, presputtering was systematically carried out for $1 \mathrm{~h}$ in order to clean the target surface. The distance between the target and the substrate was fixed at $8 \mathrm{~cm}$. Sputtering was performed in a pure argon or a mixed argon/oxygen plasma having an oxygen concentration varying from 0 to $15 \%$. The total pressure was set at different values between $0.5 \mathrm{~Pa}$ and $8 \mathrm{~Pa}$ and the power was fixed to $60 \mathrm{~W}$ which corresponds to a power density of $3 \mathrm{~W} \cdot \mathrm{cm}^{-2}$. Deposition time was adjusted so that the thickness of the films was close to $500 \mathrm{~nm}$, with an exception for samples dedicated to Rutherford Backscattering Spectroscopy (RBS) characterization for which the thickness was limited to $100 \mathrm{~nm}$. Film thickness was measured using a stylus profilometer (Veeco-Dektak $6 \mathrm{M}$ ). Several substrates were used depending on the characterization method: stainless steel and Pt (diameter $14 \mathrm{~mm}$ ), for XRD analysis, EPMA (Electron Probe X-ray MicroAnalyzer), X-ray photoelectron spectroscopy and electrochemical measurements, silicon wafer for RBS measurements and pure aluminum $(99.999 \%)$ for Mössbauer spectroscopy experiments. Sputtered thin films were annealed in air for 2 $\mathrm{h}$ at various temperatures between $200^{\circ} \mathrm{C}$ and $500^{\circ} \mathrm{C}$ after deposition.

\subsection{Characterization of thin films}

Elemental analyses were performed using an Electron Probe X-ray Micro Analyzer (EPMA) equipped with a CAMECA SX 100 Bruker. RBS experiments were carried out on $100 \mathrm{~nm}$ thick films by using a $2-\mathrm{MeV} \mathrm{He}$ ion beam at a backscattering angle of $150^{\circ}$ using a silicon particle detector [25]. The composition and thickness of the thin films were determined by processing RBS 
raw data with the SIMNRA software [26]. Experimental errors of RBS are close to 3\% for Fe and Mo elements and $10 \%$ for oxygen content.

X-ray diffraction (XRD) was carried out using a PANalytical X'Pert with CuKa radiation $(\lambda=1.5418 \AA$ A). In-situ temperature X-ray diffraction (XRD) patterns were collected on a X'pert Pro PANalytical Bragg-Brentano $\theta-\theta$ geometry diffractometer equipped with a X'Celerator detector and an Anton-Paar HTK1200 temperature chamber. The thin film deposited on Pt foil was heated at a $2^{\circ} \mathrm{C} / \mathrm{min}$ rate from room temperature to $550^{\circ} \mathrm{C}$. Before each measurement, the temperature was maintained for 15 min to ensure its stabilization.

Raman scattering measurements were performed with a Horiba Jobin Yvon Labram HR-800 microspectrometer. Spectra were recorded using a $514.5 \mathrm{~nm}$ excitation wavelength of an $\mathrm{Ar}^{+}$laser, with a power adjusted to $100 \mu \mathrm{W}$ to avoid any degradation of the sample. No specific sample preparation was needed.

The cross-section and surface morphology of the thin films were investigated by scanning electron microscopy using a Jeol 6700-F microscope. To avoid a possible charging effect induced by the electron beam on the samples, the films were systematically coated with a thin gold film before observations.

X-ray photoelectron spectroscopy (XPS) was used to investigate the local structure of the thin films. XPS analyses were carried out with a Thermo Scientific K-Alpha X-ray photoelectron spectrometer using a focused and monochromatized $\mathrm{Al} \mathrm{K \alpha}$ radiation $(1486.7 \mathrm{eV})$ (diameter of the irradiated area $=400 \mu \mathrm{m}$ ) under a residual pressure of $8 \times 10^{-7} \mathrm{~Pa}$ on thin films deposited on a stainless steel or Pt 
substrate. The spectrometer was calibrated using the photoemission lines of gold $(\mathrm{Au} 4 \mathrm{f} 7 / 2=3.9$ $\mathrm{eV}$, with reference to the Fermi level) and copper $\left(\mathrm{Cu} 2 \mathrm{p}_{3 / 2}=932.5 \mathrm{eV}\right)$. The $\mathrm{Au} 4 \mathrm{f}_{7 / 2}$ full width at a half maximum (FWHM) was $0.5 \mathrm{eV}$. In this work, the peaks were recorded with constant pass energy of $20 \mathrm{eV}$. All samples were fixed on sample holders in a glove box directly connected to the introduction chamber of the spectrometer. The XPS analyses were carried out on powder $\mathrm{Fe}_{2}\left(\mathrm{MoO}_{4}\right)_{3}$, as-deposited and annealed thin films. Peaks were then shifted to align hydrocarbon $\mathrm{C} 1 \mathrm{~s}$ photoemission to $285.0 \mathrm{eV}$ binding energy. Experimental curves were fitted with a combination of Gaussian (70\%) and Lorentzian (30\%) functions using a minimum number of components.

${ }^{57} \mathrm{Fe}$ Transmission Mössbauer spectra were measured with a $925 \mathrm{MBq}$ source of ${ }^{57} \mathrm{Co}$ in rhodium metal. During the measurements, both the source and the absorber were kept at ambient temperature $\left(21^{\circ} \mathrm{C}\right)$. The spectrometer was operated in the constant acceleration mode with a triangular velocity waveform. The velocity scale was calibrated with a high-purity $\alpha$-Fe foil at room temperature. The total thickness of the analyzed thin film sample is $2 \mu \mathrm{m}$ (with a stack of four films). The spectra were fitted to appropriate combinations of Lorentzian profiles (quadrupole doublets) by leastsquares methods. In this way, spectral parameters such as the quadrupole splitting (QS), the isomer shift (IS) and the relative resonance areas (A) of the different spectral components were determined. Isomer shifts are given relative to $\alpha$-Fe.

Lithium coin cells (2032) were assembled in an argon-filled glovebox. A lithium foil (Chemetall, battery grade) was used as the negative electrode. The separator was a bilayer composed of a polypropylene non-woven fabric (Viledon, Freundenberg) and a polypropylene microporous membrane (Celgard 2400). The electrolyte was $1 \mathrm{M} \mathrm{LiPF}_{6}$ in a 1:1 volumetric mixture of ethylene carbonate (EC) and dimethyl carbonate (DMC) (UBE Europe Gmbh). The charge/discharge cycles 
were performed with a VMP3 potentiostat/galvanostat (Bio-Logic SAS) at $25^{\circ} \mathrm{C}$ at a constant current density between 2.3 and $3.5 \mathrm{~V} / \mathrm{Li}^{+} / \mathrm{Li}$.

\section{Results and discussion}

\subsection{Composition}

In a first attempt, the influence of two sputtering parameters, namely the oxygen concentration in the discharge gas and the total pressure, on the Fe/Mo ratio of the film was thoroughly studied. Series of samples were prepared by changing a single sputtering parameter at a time while keeping the others fixed. Then, depending on the film thickness, the Fe/Mo ratio in the films was determined by combining RBS and EPMA analyses. The results gathered in table 1 show at first that an increase of the oxygen concentration in the discharge gas induces a continuous decrease of both the $\mathrm{Fe} / \mathrm{Mo}$ ratio and the deposition rate, the initial Fe/Mo ratio being close to 0.7 in absence of oxygen in the plasma and reaching 0.55 for an oxygen concentration of $15 \%$. Besides, the raising of the total pressure from 0.5 to $8 \mathrm{~Pa}$ also leads to a decrease of the Fe/Mo ratio (table 1). The latter tendency is the outcome of two simultaneous phenomena having opposite influence on the deposition rate: in the chamber, (i) the presence of a larger amount of species in the gaseous phase favors the sputtering process, (ii) in the same time sputtered particles undergo more collisions with the gas species since the mean free path shortens, as a consequence sputtered atoms are more likely to be scattered and do not to reach the substrate. The deposition rate being divided at least by 3 when the total pressure is raised from 0.5 to $8 \mathrm{~Pa}$ (for an oxygen concentration fixed to $5 \%$ ), the second phenomenon is therefore predominant. As the scattering of sputtered atoms is more pronounced for lighter elements (Fe), a decrease of the Fe/Mo ratio in the film is also observed. A similar trend is evidenced when the oxygen concentration is raised from 0 to $15 \%$. In this case, the deposition rate is almost divided by 3. Finally, the targeted Fe/Mo ratio is achieved for the following optimized set of parameters: $60 \mathrm{~W}\left(3 \mathrm{~W} . \mathrm{cm}^{-2}\right), 2 \mathrm{~Pa}, 5 \% \mathrm{O}_{2}$. Indeed, RBS and EPMA 
experiments show that the actual Fe/Mo ratio of thin films prepared in these sputtering conditions is $0.66 \pm 0.02$, i.e. the one for stoichiometric $\mathrm{Fe}_{2}\left(\mathrm{MoO}_{4}\right)_{3}$. Further annealing of the films does not modify the Fe/Mo ratio when the temperature is kept below $500{ }^{\circ} \mathrm{C}$.

Surface chemical composition of the different iron molybdate samples (powder, as-deposited and annealed thin films) was also studied by means of XPS. The Fe2p core peaks of the $\mathrm{Fe}_{2}\left(\mathrm{MoO}_{4}\right)_{3}$ powder and thin films before and after annealing are respectively displayed in figures $1 \mathrm{a}, 1 \mathrm{~b}$ and $1 \mathrm{c}$. Table 2 gathers all the XPS data together associated with the samples analysed. Given the spin-orbit coupling, the Fe $2 \mathrm{p}$ core peak is split into two components $\mathrm{Fe} 2 \mathrm{p}_{3 / 2}$ and $\mathrm{Fe} 2 \mathrm{p}_{1 / 2}$ with an area ratio of 2/1. The Fe2p core peak has a complex character especially when $\mathrm{Fe}^{2+}$ and $\mathrm{Fe}^{3+}$ ions are simultaneously present in one compound. Indeed, the small chemical shifts corresponding to the main $3 / 2$ and $1 / 2$ components and additional secondary structures for each oxidation states are observed. These structures correspond to spin multiplet effects leading to peak asymmetry with a broadening towards high binding energies. More, satellite peaks (shake-up type) are associated to $\mathrm{Fe}^{2+}$ and $\mathrm{Fe}^{3+}$ ions.

Reference compounds such as metallic iron $\left(\mathrm{Fe}^{0}\right), \mathrm{Fe}_{2} \mathrm{O}_{3}\left(\mathrm{Fe}^{3+}\right), \mathrm{LiFePO}_{4}\left(\mathrm{Fe}^{2+}\right)$ and $\mathrm{Fe}_{3} \mathrm{O}_{4}\left(\mathrm{Fe}^{3+} /\right.$ $\mathrm{Fe}^{2+}$ ) were analysed first. Fitting parameters such as the FWHM (full width at half maximum) of the satellite peaks, binding energy differences between main and corresponding satellite peaks $(\Delta \mathrm{E}$ main-sat peak) as well as the peaks intensity ratios for $\mathrm{Fe}^{3+}$ and $\mathrm{Fe}^{2+}$ ions $\left(\mathrm{I}_{\text {main peak }} / \mathrm{I}_{\text {sat peak }}\right.$ ) were therefore determined and used to fit $\mathrm{Fe}_{2}\left(\mathrm{MoO}_{4}\right)_{3}$ data. All the results summarized in table 2 are in agreement with the values reported in literature [27-30].

The XPS data of the three analysed samples are given in table 3 (note that for a relevant presentation of the table, we choose to report only Fe2p, Mo3d and O1s (relative to the materials) which explain why the total atomic \% for each sample is not $100 \%$. Indeed, $\mathrm{C} 1 \mathrm{~s}$ (CHx, C-O and $\mathrm{C}=\mathrm{O}$ contributions) and $\mathrm{O} 1 \mathrm{~s}$ (mainly $\mathrm{O}-\mathrm{C}$ and $\mathrm{O}=\mathrm{C}$ ) should be added for an exhaustive 
presentation, but we can consider that these informations are not essential for this paper. The decomposition of the $\mathrm{Fe} 2 \mathrm{p}$ core peaks shown in figure 1 leads to an average oxidation number of 2.8 for the powder and the annealed thin film, and 2.9 for the as-deposited one. Therefore, this confirms that the majority of iron is present as $\mathrm{Fe}^{3+}$ in all samples in agreement with Mössbauer measurements exhibiting only the presence of $\mathrm{Fe}^{3+}$ (figure 2). The unexpected presence of $\mathrm{Fe}^{2+}$ ions is probably related to oxygen deficiency at the very surface of the samples. This point is strengthened by the fact that XPS analyses performed on samples (as deposited and annealed thin films) mechanically etched in ultra-high vacuum reveal a significantly lower contribution of $\mathrm{Fe}^{2+}$ species below the pristine surface.

It is worth noting that the Fe2p core peak becomes more defined and displays lower width for the annealed $\mathrm{Fe}_{2}\left(\mathrm{MoO}_{4}\right)_{3}$ film compared to the as-deposited one, consistently with the enhanced crystallinity obtained after annealing. The same trend is observed if we compare the as-deposited thin film with the powder.

The Mo 3d spectra shown in figure 1d, 1e and 1f, are split in two components, Mo $3 \mathrm{~d}_{5 / 2}$ and Mo $3 \mathrm{~d}_{3 / 2}$ with an area ratio of $3 / 2$. The Mo $3 \mathrm{~d}_{5 / 2}$ component located at $232.4 \mathrm{eV}$ is attributed to $\mathrm{Mo}^{6+}$, which corresponds to the theoretical oxidation state of molybdenum in $\mathrm{Fe}_{2}\left(\mathrm{MoO}_{4}\right)_{3}$. The same evolution regarding crystallinity is observed for Mo3d core peaks which display lower full width at half maximum (FWHM) for the thin films compared to the powder and for the annealed thin film compared to as-deposited one.

The estimated Fe/Mo atomic percentage from XPS analyses for the powder, the as-deposited and the annealed thin films is $0.61,0.59$ and 0.67 respectively, which proves that the stoichiometry for the annealed thin film sample is close to the theoretical one.

Mössbauer spectra of the starting $\mathrm{Fe}_{2}\left(\mathrm{MoO}_{4}\right)_{3}$ powder and the thin film annealed at $500^{\circ} \mathrm{C}$ are both typical of a high-spin ferric ions (figure 2). The amount of $\mathrm{Fe}^{2+}$, if any, is less than the detection limit namely $1-2 \%$. Spectra were fitted with a singlet of Lorentzian of width $\Gamma$ close to $0.30 \mathrm{~mm} . \mathrm{s}^{-1}$ 
which a quadrupole splitting $\Delta$ close to $0.20 \mathrm{~mm} . \mathrm{s}^{-1}$. The isomer shift $\delta$ at $293 \mathrm{~K}$ is close to 0.40 $\mathrm{mm} . \mathrm{s}^{-1}$. The room temperature parameters (table 4) are very similar to those reported previously in literature [31]. The rather small quadrupole splitting value is indicative of only minor distortions of the $\left(\mathrm{FeO}_{6}\right)$ octahedra.

Finally, RBS, EPMA, Mössbauer and XPS analyses confirm that the targeted $\mathrm{Fe}_{2}\left(\mathrm{MoO}_{4}\right)_{3}$ composition was achieved by properly tuning the total pressure and the oxygen concentration in the chamber during the preparation of thin films by sputtering.

\subsection{Structure and morphology}

As-deposited thin films are poorly crystallized as shown by XRD pattern (figure 3a). They start to crystallize at about $340^{\circ} \mathrm{C}$. After a thermal treatment at $500{ }^{\circ} \mathrm{C}$, the resulting diffraction pattern is characteristic of a monoclinic cell (space group $\mathrm{P} 2{ }_{1} / \mathrm{a}$ ) and does not show any additional peak that could be attributed to a secondary phase. It is clearly similar to the one obtained for the powder used to prepare the target (figure $3 b$ ). The refined cell parameters obtained by the full profile matching refinement (Rietveld method) for the powder are: $a=15.736(5) \AA, b=9.246(2) \AA$, $\mathrm{c}=18.265(5) \AA, \beta=125.32(2)^{\circ}$ with a $\chi^{2}=2.99$, in agreement with the values reported in the literature [32].

Raman spectra of thin films, as-deposited and after annealing at $500^{\circ} \mathrm{C}$, are shown on figure 4 . The spectrum of the powder used to prepare the target is also included as a reference. It exhibits welldefined bands, the major ones at ca. 355, 785, 936 and $970 \mathrm{~cm}^{-1}$ being typical of Fe-O, Mo-O-Mo and $\mathrm{Mo}=\mathrm{O}$ vibrations in $\mathrm{Fe}_{2}\left(\mathrm{MoO}_{4}\right)_{3}$; the other ones visible at 993 and $824 \mathrm{~cm}^{-1}$ being assigned to stretching modes in $\mathrm{MoO}_{3}$ [33-34]. The spectrum of the as-deposited thin film displays bands at similar wavenumbers, but having a large width that is typical of a poorly crystallized material. After 
annealing at $500^{\circ} \mathrm{C}$, the spectrum becomes close to the one of the powder, and evidences the achievement of a well-crystallized $\mathrm{Fe}_{2}\left(\mathrm{MoO}_{4}\right)_{3}$ thin film.

As highlighted by the presence of sharp peaks on the XRD patterns and Raman spectra, an annealing step is required to get well-crystallized thin films.

Scanning electron microscopy (SEM) images of the surface and the cross-section of the asdeposited thin film and of the one annealed at $500^{\circ} \mathrm{C}$ are shown on figure 5. The surface of the asdeposited film (figure 5a) appears very homogeneous and made of very small grains (around $10 \mathrm{~nm}$ size). The thermal treatment does not induce a marked change of the thin film morphology, but only a slight increase of the apparent grain size $(20-30 \mathrm{~nm})$. The cross section of the as-deposited sample (figure 5c) reveals the dense character of the film and a typical columnar growth, the column width being consistent with the apparent size of the grain present at the surface and being quite constant from the bottom to the top. Once annealed at $500^{\circ} \mathrm{C}$, the only apparent change of the film morphology is a homogenous widening of the columnar grains up to $30 \mathrm{~nm}$ in diameter (figure $5 \mathrm{~d}$ ). The dense character of the films, both prior and after annealing, and the smooth character of their outer surface are real assets for the integration of these films in all-solid-state microbatteries since they will allow to get good contact between the electrode and the solid electrolyte (LiPON) deposited by sputtering at the top of the latter. Nevertheless, at this stage of the study, these morphological characters are expected to be rather detrimental to the electrochemical performance of the electrode since such a morphology prevents the liquid electrolyte to penetrate the film and to boost the ionic transport inside the electrode. In any case, the slight variation of the film morphology observed after the thermal treatment is not expected to play an important role on the electrochemical response of the material. 


\subsection{Electrochemical characterization}

The electrochemical characterization of $500 \mathrm{~nm}$ thick $\mathrm{Fe}_{2}\left(\mathrm{MoO}_{4}\right)_{3}$ films deposited with optimized conditions $\left(60 \mathrm{~W}, 2 \mathrm{~Pa}, 5 \% \mathrm{O}_{2}\right)$ was performed in coin cells using a $\mathrm{Li}$ metal negative electrode and a liquid electrolyte. The charge/discharge cycles were performed at a constant current density between 2.3 and $3.5 \mathrm{~V} / \mathrm{Li}^{+} / \mathrm{Li}$, the lower cut-off voltage was chosen to avoid the reduction of $\mathrm{Mo}^{6+}$ into $\mathrm{Mo}^{4+}$ that would induce an irreversible modification of the initial structure [10].

First galvanostatic cycles for as-deposited samples and films annealed at 200, 300, 400 or $500{ }^{\circ} \mathrm{C}$ displayed on figure 6a, show that almost $2 \mathrm{Li}^{+}$ions per $\mathrm{Fe}_{2}\left(\mathrm{MoO}_{4}\right)_{3}$ can be inserted in the thin film material during the first discharge whatever the annealing temperature. Nevertheless, in absence of thermal treatment or after a moderate annealing (temperature not higher than $300{ }^{\circ} \mathrm{C}$ ), the films display a poor electrochemical performance (figure 3a) that is related to their low crystallinity. Thus, the voltage curves of these samples do not exhibit any marked plateau and a large part of $\mathrm{Li}^{+}$ ions cannot be removed during the first charge. It has to be noted that the open circuit voltage for the as-deposited thin film is slightly higher than the one for annealed films $(3.7 \mathrm{~V}$ instead $3.2 \mathrm{~V} /$ $\mathrm{Li}^{+} / \mathrm{Li}$ ). Finally, only $0.9,0.3$ and $0.4 \mathrm{Li}^{+}$ions per formula unit can be respectively de-inserted from the as-deposited sample and thin films annealed at 200 or $300^{\circ} \mathrm{C}$. On subsequent cycles, the discharge capacity value stabilizes at a value corresponding to less than $30 \%$ of the theoretical capacity (figure 6b). On the contrary, after a thermal treatment at 400 and $500^{\circ} \mathrm{C}$, the discharge and charge curves display a very flat plateau at about $3 \mathrm{~V}$ and a very low polarization $(\sim 50 / 2 \mathrm{mV})$ (figure $6 \mathrm{a}$ and $6 \mathrm{c}$ ). The flatness of the open circuit voltage curve is consistent with a two phase reaction $\mathrm{Fe}_{2}\left(\mathrm{MoO}_{4}\right)_{3}+2 \mathrm{Li}^{+}+2 \mathrm{e}^{-} \leftrightarrows \mathrm{Li}_{2} \mathrm{Fe}_{2}\left(\mathrm{MoO}_{4}\right)_{3}$ reported in the literature [10]. During the first discharge, about $2 \mathrm{Li}^{+}$ions are inserted per formula unit corresponding to the formation of the $\mathrm{Li}_{2} \mathrm{Fe}_{2}\left(\mathrm{MoO}_{4}\right)_{3}$ phase and the reduction of $\mathrm{Fe}^{3+}$ ions into $\mathrm{Fe}^{2+}$ ones (confirmed by ex situ Mössbauer analyses not shown here). Despite the fact that the shape of the voltage curves is the same for thin film electrodes annealed at $400^{\circ} \mathrm{C}$ and $500^{\circ} \mathrm{C}$, the sample annealed at a higher temperature exhibits a significantly lower capacity loss at the first cycle and a better capacity retention during subsequent 
cycles, retaining around $90 \%$ of the initial capacity after 20 cycles (figure 6b). Therefore, a wellcrystalline film is mandatory to get the best electrochemical performance.

The first sweep voltametry cycle (figure $6 \mathrm{~d}$ ) for the thin film annealed at $500^{\circ} \mathrm{C}$ displays one asymmetric peak in reduction with a maximum at $2.92 \mathrm{~V}$ and a sharper peak in oxidation at $3.05 \mathrm{~V}$. Surprisingly, during the second cycle, the peak in reduction is clearly made of components at 2.967 $\mathrm{V}$ and $2.923 \mathrm{~V}$, while the shape of the subsequent oxidation peak remain quite unchanged. This tendency was observed systematically on different samples. Due to the tiny potential difference between the two peaks, this phenomenon cannot be observed on the galvanostatic curve, but is visible on the derivative plots of the capacity $v s$ potential curves for electrodes cycled at constant current. Such a two-step behavior, but with a larger gap between the two reduction peaks, was observed on voltametric curves during Na insertion [21]. This behavior is likely to be related to the generation of a compressive stress in the film, parallel to the substrate, induced by the swelling of the material during its lithiation (+6 vol.\%), and which would be absent or delayed in a part of the electrode material after the first swelling-shrinkage cycle. Indeed, it is well-known that the stress caused by the volume expansion of electrode materials during its lithiation can modify both their open circuit voltage at equilibrium and their reaction over-potential at non-equilibrium [35].

Finally, the influence of the current rate on the capacity retention of the thin film electrode annealed at $500^{\circ} \mathrm{C}$ (figure 7) was studied. As already mentioned, the volumetric capacity is higher than 30 $\mu \mathrm{Ah} . \mathrm{cm}^{-2} \cdot \mu \mathrm{m}^{-1}$ for the first cycle achieved at C/20 (figure $7 \mathrm{a}$ ), which is very close to the theoretical specific capacity for this material $\left(33 \mu \mathrm{Ah} \cdot \mathrm{cm}^{-2} \cdot \mu \mathrm{m}^{-1}\right)$. This capacity remains quite stable around 27 $\mu \mathrm{Ah} . \mathrm{cm}^{-2} . \mu \mathrm{m}^{-1}$ during 30 cycles. When the current density is significantly increased $(\mathrm{C}$ rate $)$, the delivered capacity is drastically reduced to $32 \%$ of the initial value, while remaining stable over several hundreds of cycles. Subsequently, when cycling at a C/20 rate is resumed, it appears that the 
capacity drop is fully reversible, hence that the latter originates from a limitation on the motion of either $\mathrm{Li}^{+}$or $\mathrm{e}^{-}$in the film. The voltage curves measured at $\mathrm{C} / 20$ and $\mathrm{C}$ rates (figure $7 \mathrm{~b}$ ) indicate a slight increase of the polarization (30 to $90 \mathrm{mV}$ ) on the plateau, but a large increase of the concentration polarization near the end of charge/discharge responsible for the limitation of the amount of $\mathrm{Li}^{+}$that can be inserted/extracted at high rate. The low kinetics of the electrode reaction is probably favored by the two-phase mechanism that contributes to maintain the electronic conductivity of the electrode material at a low level during the course of the electrochemical reaction (absence of a mixed valence cations) [20]. The two-phase transformation at room temperature from monoclinic $\mathrm{Fe}_{2}\left(\mathrm{MoO}_{4}\right)_{3}$ to orthorhombic $\mathrm{Li}_{2} \mathrm{Fe}_{2}\left(\mathrm{MoO}_{4}\right)_{3}$ is not likely to favor the kinetics of lithium intercalation because: the phase separation of $\mathrm{Fe}_{2}\left(\mathrm{MoO}_{4}\right)_{3}$ containing only $\mathrm{Fe}^{3+}$ species and $\mathrm{Li}_{2} \mathrm{Fe}_{2}\left(\mathrm{MoO}_{4}\right)_{3}$ containing only $\mathrm{Fe}^{2+}$ does not favor a facile electronic transport through the film (absence of solid solution and single-phased material containing both $\mathrm{Fe}^{3+}$ and $\mathrm{Fe}^{2+}$;

(ii) the phase boundary is generally an obstacle to the $\mathrm{Li}^{+}$diffusion [36].

\section{Conclusion}

Iron molybdate $\mathrm{Fe}_{2}\left(\mathrm{MoO}_{4}\right)_{3}$ thin films were prepared by radio-frequency sputtering from a homemade target using adequate oxygen concentration and total pressure in order to get the stoichiometric composition, which was checked by RBS and EPMA analyses. Results from Mössbauer and XPS experiments, showing that $\mathrm{Mo}^{6+}$ and $\mathrm{Fe}^{3+}$ are the main detected species, were also consistent with the achievement of a $\mathrm{Fe}_{2}\left(\mathrm{MoO}_{4}\right)_{3}$ composition. Post-deposition annealing was necessary to get well-crystallized thin films displaying good electrochemical performances. Therefore, it was demonstrated for the first time the possible use of this material as a positive electrode in lithium thin film batteries. Best capacity value and capacity retention were obtained for 
thin films annealed at $500^{\circ} \mathrm{C}$, cycled between $2.3 \mathrm{~V}$ and $3.5 \mathrm{~V} v s \mathrm{Li}^{+} / \mathrm{Li}$ at a $\mathrm{C} / 20$ regime in liquid electrolyte cells.

\section{Acknowledgments}

Authors acknowledge L. Teule-Gay and C. Denage (ICMCB) for their help with thin film deposition and SEM characterization respectively, S. Sorieul from AIFIRA ion beam analysis facility (CENBG-CNRS/IN ${ }_{2} \mathrm{P}_{3}$ - Bordeaux University) for RBS analyses and French Ministry of Industry for its financial support through Project Investissement d'Avenir Tours 2015 in collaboration with STMicroelectronics. 


\section{References}

[1] B. Wang, J. B. Bates, F. X. Hart, B. C. Sales, R. A. Zuhr, J. D. Robertson, Characterization of thin film rechargeable lithium batteries with lithium cobalt oxide cathodes, J. Electrochem. Soc. 143 (1996) 3203-3213.

[2] S. Cotte, B. Pecquenard, F. Le Cras, R. Grissa, H. Martinez, L. Bourgeois, Lithium-rich manganese oxide spinel thin films as 3V electrode for lithium batteries, Electrochim. Acta 180 (2015) 528-534.

[3] A. W. Sleight, B. L. Chamberland, Transition metal molybdates of the type $\mathrm{AMoO}_{4}$, Inorg. Chem. 7 (1968) 1672-1675.

[4] W. Kuang, Y. Fan, Y. Chen, Structure and reactivity of ultrafine Fe-Mo oxide particles prepared by the sol-gel method, Langmuir 16 (2000) 5205-5208.

[5] S. D. M. Jacques, O. Leynaud, D. Strusevich, A.M. Beale, G. Sankar, C. M. Martin, P. Barnes, Redox behavior of Fe-Mo-O catalysts studied by ultrarapid in situ diffraction, Angew. Chem. Int. Ed. 45 (2006) 445-448.

[6] Ü. Kersen, L. Holappa, Surface characterization and $\mathrm{H}_{2} \mathrm{~S}$-sensing potential of iron molybdate particles produced by supercritical solvothermal method and subsequent oxidation, Appl. Phys. A 85 (2006) 431-436.

[7] X. Wu, G. Yu, X. Chen, Y. Wang, C. Liu, Reduction/reoxidation of a multicomponent molybdate catalyst for propylene ammoxidation, Thermochim. Acta 486 (2009) 20-26.

[8] A. P. V. Soares, M. Farinha Portela, A. Kiennemann, L. Hilaire, J. M. M. Millet, Iron molybdate catalysts for methanol to formaldehyde oxidation: Effects of Mo excess on catalytic behaviour, Appl. Catal., A 206 (2001) 221-229. 
[9] H. Ehrenberg, K. G. Bramnik, E. Muessig, T. Buhrmester, H. Weitzel, C. Rittel, The ferrimagnetic structure of $\mathrm{Fe}_{2} \mathrm{Mo}_{3} \mathrm{O}_{12}$ : dependence of $\mathrm{Fe}-\mathrm{O}-\mathrm{O}-\mathrm{Fe}$ supersuperexchange couplings on geometry, J. Magn. Magn. Mater. 261 (2003) 353-359.

[10] A. Manthiram, J. B. Goodenough, Lithium insertion into $\mathrm{Fe}_{2}\left(\mathrm{MO}_{4}\right)_{3}$ frameworks: comparison of $\mathrm{M}=\mathrm{W}$ with $\mathrm{M}=\mathrm{Mo}$, J. Solid State Chem. 71 (1987) 349-360.

[11] H. Y. Chen, The crystal structure and twinning behavior of ferric molybdate $\mathrm{Fe}_{2}\left(\mathrm{MoO}_{4}\right)_{3}$, Mat. Res. Bull. 14 (1979) 1583-1590.

[12] W. M. Shaheen, Thermal behaviour of pure and binary $\mathrm{Fe}\left(\mathrm{NO}_{3}\right)_{3} \cdot 9 \mathrm{H}_{2} \mathrm{O}$ and $\left(\mathrm{NH}_{4}\right)_{6} \mathrm{Mo}_{7} \mathrm{O}_{24}$. $4 \mathrm{H}_{2} \mathrm{O}$ systems, Mater. Sci. Eng., A 445-446 (2007) 113-121.

[13] D. D. Radev, V. Blaskov, D. Klissurski, I. Mitov, A. Toneva, Effect of the mechanical activation of the reagents on the solid phase synthesis of iron (III) molybdate, J. Alloys Compd. 256 (1997) 108-111.

[14] S. H. Tian, Y. T. Tu, D. S. Chen, X. Chen, Y. Xiong, Degradation of Acid Orange II at neutral pH using $\mathrm{Fe}_{2}\left(\mathrm{MoO}_{4}\right)_{3}$ as a heterogeneous Fenton-like catalyst, Chem. Eng. J. 169 (2011) 31-37.

[15] C. Peng, L. Gao, S. Yang and J. Sun, A general precipitation strategy for large-scale synthesis of molybdate nanostructures, Chem. Commun. 43 (2008) 5601-5603.

[16] Y. Ding, S. H. Yu, C. Liu, and Z. A Zang, 3D Architectures of iron molybdate: phase selective synthesis, growth mechanism, and magnetic properties, Chem. Eur. J. 13 (2007) 746-753.

[17] L. Zhang, X. F. Cao, Y. L. Ma, X. T. Chen and Z. L. Xue, Pancake-like $\mathrm{Fe}_{2}\left(\mathrm{MoO}_{4}\right)_{3}$ microstructures: microwave-assisted hydrothermal synthesis, magnetic and photocatalytic properties, New J. Chem. 34 (2010) 2027-2033.

[18] A. Nadiri, C. Delmas, R. Salmon, P. Hagenmuller, Chemical and electrochemical alkali metal intercalation in the 3D-framework of $\mathrm{Fe}_{2}\left(\mathrm{MoO}_{4}\right)_{3}$, Rev. Chim. Miner. 21 (1984) 537-544. 
[19] W.M. Reiff, J. H. Zhang, C. C. Torardi, Topochemical lithium insertion into $\mathrm{Fe}_{2}\left(\mathrm{MoO}_{4}\right)_{3}$ : structure and magnetism of $\mathrm{Li}_{2} \mathrm{Fe}_{2}\left(\mathrm{MoO}_{4}\right)_{3}$, J. Solid State Chem. 62 (1986) 231-240.

[20] P. Forzatti, P. L. Villa, C. M. Mari, Electrical conductivity of polycrystalline $\mathrm{Fe}_{2}\left(\mathrm{MoO}_{4}\right)_{3}$, Mater. Chem. Phys. 10 (1984) 385-391.

[21] Q. Sun, Q. Q. Ren, Z. W. Fu, Nasicon-type $\mathrm{Fe}_{2}\left(\mathrm{MoO}_{4}\right)_{3}$ thin film as cathode for rechargeable sodium ion battery, Electrochem. Comm. 23 (2012)145-148.

[22] J. Sheng, H. Zang, C. Tang, Q. An, Q. Wei, G. Zhang, L. Chen, C. Peng, L. Mai, Graphene wrapped nasicon-type $\mathrm{Fe}_{2}\left(\mathrm{MoO}_{4}\right)_{3}$ nanoparticle as ultra high rate cathode for $\mathrm{Na}$ batteries, Nano Energy 24 (2016) 130-138.

[23] Y. Niu, M. Xu, Reduced graphene oxide and composite for sodium-ion batteries cathode with improved performance, J. Alloys Compd., 674 (2016) 392-398

[24] V. Nguyen, Y. Liu, X. Yang, W. Chen, $\mathrm{Fe}_{2}\left(\mathrm{MoO}_{4}\right)_{3} /$ nanosilver composite as a cathode for sodium-ion batteries, ECS Electrochem. Lett., 4 (2015) A29-A32

[25] S. Sorieul, P. Alfaurt, L. Daudin, L. Serani, P. Moretto, Aifira: an ion beam facility for multidisciplinary research, Nucl. Instrum. Methods Phys. Res., Sect. B: 332 (2014) 68-73.

[26] M. Mayer, SIMNRA, a simulation program for the analysis of NRA, RBS and ERDA, Proceedings of the 15th International Conference on the Application of Accelerators in Research and Industry, J.L. Duggan and I.L. Morgan (eds.), American Institute of Physics Conference Proceedings 475 (1999) 541-544

[27] A. P. Grosvenor, B. A. Kobe, M. C. Biesinger, N. S. McIntyre, Investigation of multiplet splitting of Fe 2p XPS spectra and bonding in iron compounds, Surf. Interface Anal. 36 (2004) 1564-1574. 
[28] L. Castro, R. Dedryvère, M. El Khalifi, P.E. Lippens, J. Bréger, C. Tessier, The spin-polarized electronic structure of $\mathrm{LiFePO}_{4}$ and $\mathrm{FePO}_{4}$ evidenced by in-lab XPS, J. Phys. Chem. C. 114 (2010) 17995-18000.

[29] M. Muhler, J. Schutze, M. Wesemann, T. Rayment, A. Dent, R. Schlogl, The nature of the iron oxide-based catalyst for dehydrogenation of ethylbenzene to styrene, solid State chemistry and bulk characterization, J. Catal. 126 (1990) 339-360.

[30] P.Mills, J L. Sullivan, A study of the core level electrons in iron and its three oxides by means of x-ray photoelectron spectroscopy, J. Phys. D Appl. Phys. 16 (1983) 723-732.

[31] Z. Jirak, R. Salmon, L. Fournes, F. Menil, P. Hagenmuller, Magnetic and Mössbauer resonance investigations of the weak ferrimagnet $\mathrm{Fe}_{2}\left(\mathrm{MoO}_{4}\right)_{3}$, Inorg. Chem. 21 (1982) 4218-4223.

[32] M. H. Rapposch, J. B. anderson, E. Kostiner, Crystal structure of ferric molybdate, $\mathrm{Fe}_{2}\left(\mathrm{MoO}_{4}\right)_{3}$, Inorg. Chem. 19 (1980) 3531-3539.

[33] C. G. Hill, J. H. Wilson, Raman spectroscopy of iron molybdate catalyst systems: Part I. Preparation of unsupported catalysts, J. Mol. Catal. 63 (1990) 65-94.

[34] Q. Xu, G. Jia, J. Zhang, Z. Feng, C. Li, Surface phase composition of iron molybdate catalysts studied by UV Raman spectroscopy, J. Phys. Chem. C 112 (2008) 9387-9393.

[35] B. Lu, Y. Song, Q. Zhang, J. Pan, Y.-T. Cheng, J. Zhang, Voltage hysteresis of lithium ion batteries caused by mechanical stress, Phys. Chem. Chem. Phys. 18 (2016) 4721-472

[36] F. Liu, N. A. Siddique, P. P. Mukherjee, Nonequilibrium phase transformation and particle shape effect in $\mathrm{LiFePO}_{4}$ Materials for Li-Ion Batteries, Electrochem. Solid State Lett. 14 (2011) A143-A147 


\section{Table captions}

Table 1 : Fe/Mo ratio and deposition rate for iron molybdate thin films prepared at various total pressures and oxygen concentrations in the discharge gas.

Table 2: Fe2p core peaks deconvolution parameters

Table 3: XPS data (Fe2p, Mo3d, O1s) and surface composition of $\mathrm{Fe}_{2}\left(\mathrm{MoO}_{4}\right)_{3}$ powder and thin films prior and after annealing at $500^{\circ} \mathrm{C}$.

Table 4: Mössbauer parameters of $\mathrm{Fe}_{2}\left(\mathrm{MoO}_{4}\right)_{3}$ powder and thin film at room temperature 


\begin{tabular}{c|c|c|c}
\hline Total pressure (Pa) & $\begin{array}{c}\text { Oxygen } \\
\text { concentration (\%) }\end{array}$ & Fe/Mo ratio & $\begin{array}{c}\text { Deposition rate } \\
\left(\mathbf{n m} \cdot \mathbf{h}^{-1}\right)\end{array}$ \\
\hline 0.5 & 5 & $0.74 \pm 0.02$ & 170 \\
2 & 5 & $0.66 \pm 0.02$ & 130 \\
8 & 5 & $0.63 \pm 0.02$ & 50 \\
2 & 0 & $0.72 \pm 0.02$ & 250 \\
2 & 10 & $0.60 \pm 0.02$ & 95 \\
2 & 15 & $0.55 \pm 0.02$ & 90 \\
\hline
\end{tabular}

Table 1 


\begin{tabular}{|c|c|c|c|}
\hline Iron oxidation states & $\mathrm{Fe}^{0}$ & $\mathrm{Fe}^{2+}$ & $\mathrm{Fe}^{3+}$ \\
\hline B.E. of the main peak $2 \mathrm{p} 3 / 2( \pm 0.2 \mathrm{eV})$ & 706.7 & 709.6 & 711.7 \\
\hline$\Delta$ main $3 / 2$ peak-sat $3 / 2$ peak $(\mathrm{eV})$ & - & 5.8 & 8.7 \\
\hline I (main 3/2 peak) / I (sat.3/2 peak) & - & 0.4 & 0.075 \\
\hline satellite peaks FWHM $( \pm 0.2 \mathrm{eV})$ & - & 4.2 & 2.9 \\
\hline
\end{tabular}

Table 2 


\begin{tabular}{|c|c|c|c|c|c|c|c|}
\hline & \multicolumn{2}{|c|}{ Powder } & \multicolumn{2}{|c|}{ As-dep. thin film } & \multicolumn{2}{|c|}{$\begin{array}{l}\text { Thin film annealed } \\
\text { at }\left(500^{\circ} \mathrm{C}\right)\end{array}$} & \\
\hline & $\begin{array}{l}\mathrm{BE}(\mathrm{eV}) \\
\text { (FWHM ) }\end{array}$ & $\begin{array}{c}\text { Atomic } \\
\%\end{array}$ & $\begin{array}{l}\mathrm{BE}(\mathrm{eV}) \\
\text { (FWHM) }\end{array}$ & Atomic \% & $\begin{array}{l}\mathrm{BE}(\mathrm{eV}) \\
\text { (FWHM) }\end{array}$ & Atomic \% & \\
\hline & $\begin{array}{l}709.6 \\
(1.7)\end{array}$ & 0.8 & $\begin{array}{c}709.6 \\
(1.7)\end{array}$ & 0.3 & $\begin{array}{c}709.4 \\
(1.8)\end{array}$ & 0.5 & $\mathrm{Fe}^{2+}$ Main peak \\
\hline & $\begin{array}{c}711.9 \\
(--)\end{array}$ & 3.8 & $\begin{array}{c}711.7 \\
(--)\end{array}$ & 5.5 & $\begin{array}{c}711.7 \\
(-)\end{array}$ & 5.7 & $\mathrm{Fe}^{3+}$ Main component \\
\hline Fe 2p & $\begin{array}{l}715.3 \\
(4.2)\end{array}$ & 0.3 & $\begin{array}{c}715.3 \\
(4.2)\end{array}$ & 0.1 & $\begin{array}{c}715.1 \\
(4.2)\end{array}$ & 0.2 & $\mathrm{Fe}^{2+}$ Sat. peak \\
\hline & $\begin{array}{c}720.6 \\
(2.9)\end{array}$ & & $\begin{array}{c}720.4 \\
(2.9)\end{array}$ & & $\begin{array}{c}720.4 \\
(2.9)\end{array}$ & & $\mathrm{Fe}^{3+}$ Sat peak \\
\hline$\% \mathrm{Fe}$ & & 5.2 & & 6.3 & & 6.8 & \\
\hline Mo $3 d_{5 / 2}$ & $\begin{array}{c}232.4 \\
(1.2)\end{array}$ & 5.1 & $\begin{array}{c}232.4 \\
(1.1)\end{array}$ & 6.4 & $\begin{array}{c}232.4 \\
(1.0)\end{array}$ & 6.1 & \\
\hline Mo $3 d_{3 / 2}$ & $\begin{array}{c}235.6 \\
(1.1)\end{array}$ & & $\begin{array}{c}235.6 \\
(1.0)\end{array}$ & & $\begin{array}{c}235.6 \\
(1.0)\end{array}$ & & \\
\hline$\%$ Mo & & 8.5 & & 10.7 & & 10.1 & \\
\hline $01 \mathrm{~s}$ & $\begin{array}{c}530.9 \\
(1.2)\end{array}$ & 31.5 & $\begin{array}{c}530.7 \\
(1.1) \\
\end{array}$ & 40.8 & $\begin{array}{c}530.6 \\
(1.0) \\
\end{array}$ & 38.8 & $\mathrm{O}\left[\mathrm{Fe}_{2}\left(\mathrm{MoO}_{4}\right)_{3}\right]$ \\
\hline
\end{tabular}

Table 3 


\begin{tabular}{c|c|c|}
\hline Parameters & Powder & As-dep. thin film \\
\hline$\delta$ Isomeric shift $\left(\mathbf{m m} . \mathbf{s}^{-1}\right)$ & $0.41(1)$ & $0.39(2)$ \\
\hline$\Delta$ Quadrupole splitting $\left(\mathbf{m m} \cdot \mathbf{s}^{-1}\right)$ & $0.18(2)$ & $0.20(3)$ \\
\hline$\Gamma$ full width at half maximum $\left(\mathbf{m m} \cdot \mathbf{s}^{-1}\right)$ & $0.30(2)$ & $0.31(2)$ \\
\hline
\end{tabular}

Table 4 


\section{Figure captions}

Figure 1 : XPS spectra of Fe 2p and Mo $6 \mathrm{~d}$ for $\mathrm{Fe}_{2}\left(\mathrm{MoO}_{4}\right)_{3}$ powder (a, d), as-deposited (b, e) and annealed at $500{ }^{\circ} \mathrm{C}$ thin films $(\mathrm{c}, \mathrm{f})$.

Figure 2 : Room temperature ${ }^{57} \mathrm{Fe}$ Mössbauer spectra of a $\mathrm{Fe}_{2}\left(\mathrm{MoO}_{4}\right)_{3}$ thin film after $500{ }^{\circ} \mathrm{C}$ annealing and $\mathrm{Fe}_{2}\left(\mathrm{MoO}_{4}\right)_{3}$ powder.

Figure 3 : a) In situ XRD patterns of a $\mathrm{Fe}_{2}\left(\mathrm{MoO}_{4}\right)_{3}$ thin film measured during a staircase annealing between room temperature and $500{ }^{\circ} \mathrm{C}$. b) Comparison of XRD patterns of the $\mathrm{Fe}_{2}\left(\mathrm{MoO}_{4}\right)_{3}$ powder and the thin film annealed at $500^{\circ} \mathrm{C}$. A Rietveld refinement was achieved to precisely determine the cell parameters of the powder.

Figure 4: Raman spectra of $\mathrm{Fe}_{2}\left(\mathrm{MoO}_{4}\right)_{3}$ thin films, as-deposited and after annealing at $500^{\circ} \mathrm{C}(\operatorname{Raman}$ spectrum of the $\mathrm{Fe}_{2}\left(\mathrm{MoO}_{4}\right)_{3}$ powder is shown as a reference).

Figure 5 : Surface and cross-section SEM images of $\mathrm{Fe}_{2}\left(\mathrm{MoO}_{4}\right)_{3}$ thin films; a,c) as-deposited and b,d) after annealing at $500^{\circ} \mathrm{C}$.

Figure 6 : Voltage-composition profiles at $\mathrm{C} / 20$ a) and capacity retention b) for the $\mathrm{Fe}_{2}\left(\mathrm{MoO}_{4}\right)_{3}$ thin films as a function of the annealing temperature. c) Open circuit voltage (OCV) and dynamic voltage curves $(\mathrm{C} / 20)$ for a thin film annealed at $500^{\circ} \mathrm{C}$. d) Cyclic voltammetry for a $\mathrm{Fe}_{2}\left(\mathrm{MoO}_{4}\right)_{3}$ thin film annealed at $500^{\circ} \mathrm{C}$. 
Figure 7 : Evolution of the capacity and coulombic efficiency a) and b) voltage curves for $\mathrm{Fe}_{2}\left(\mathrm{MoO}_{4}\right)_{3}$ thin films annealed at $500^{\circ} \mathrm{C}$ as a function of the current rate. 
Figure 1
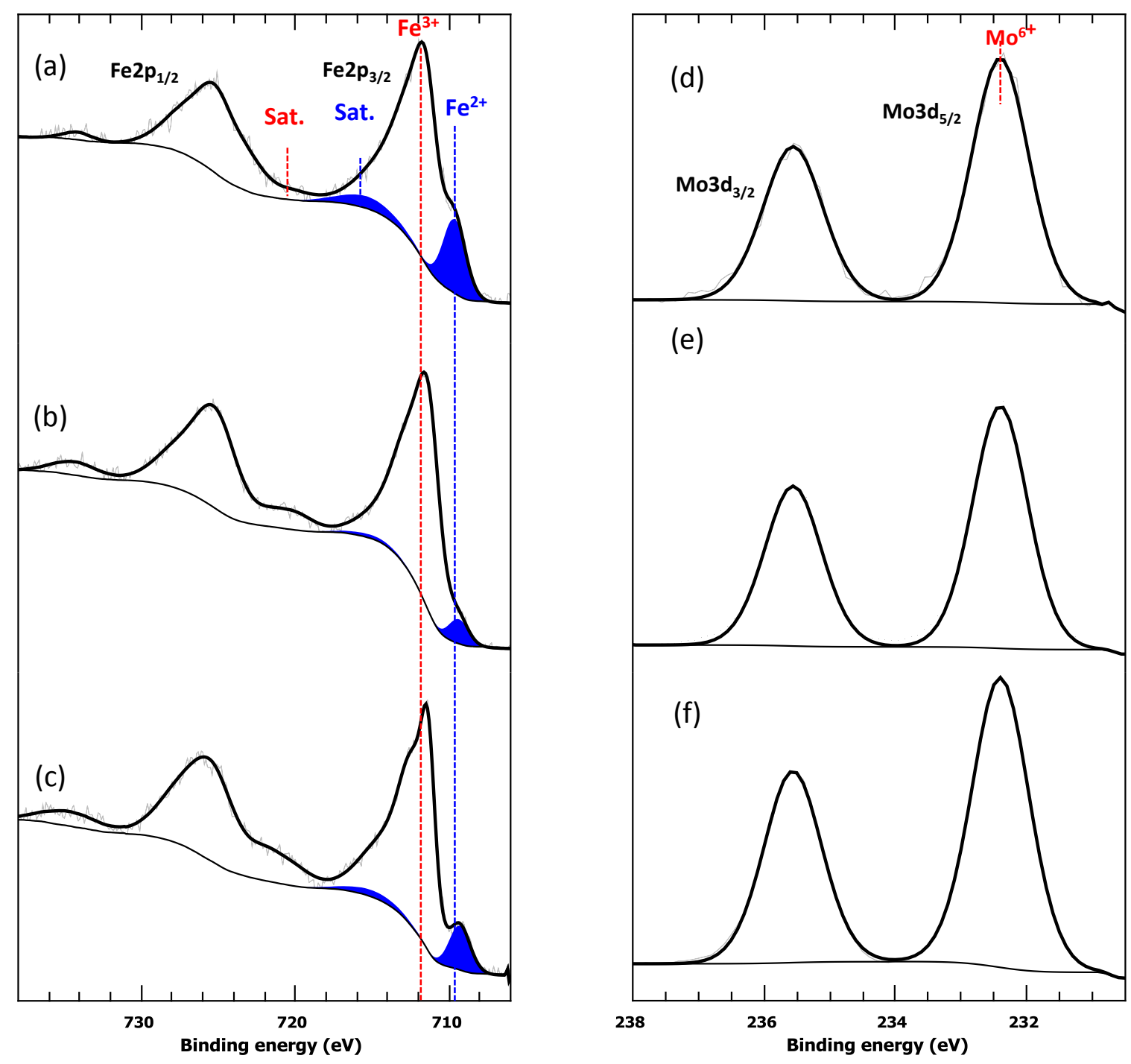
Figure 2

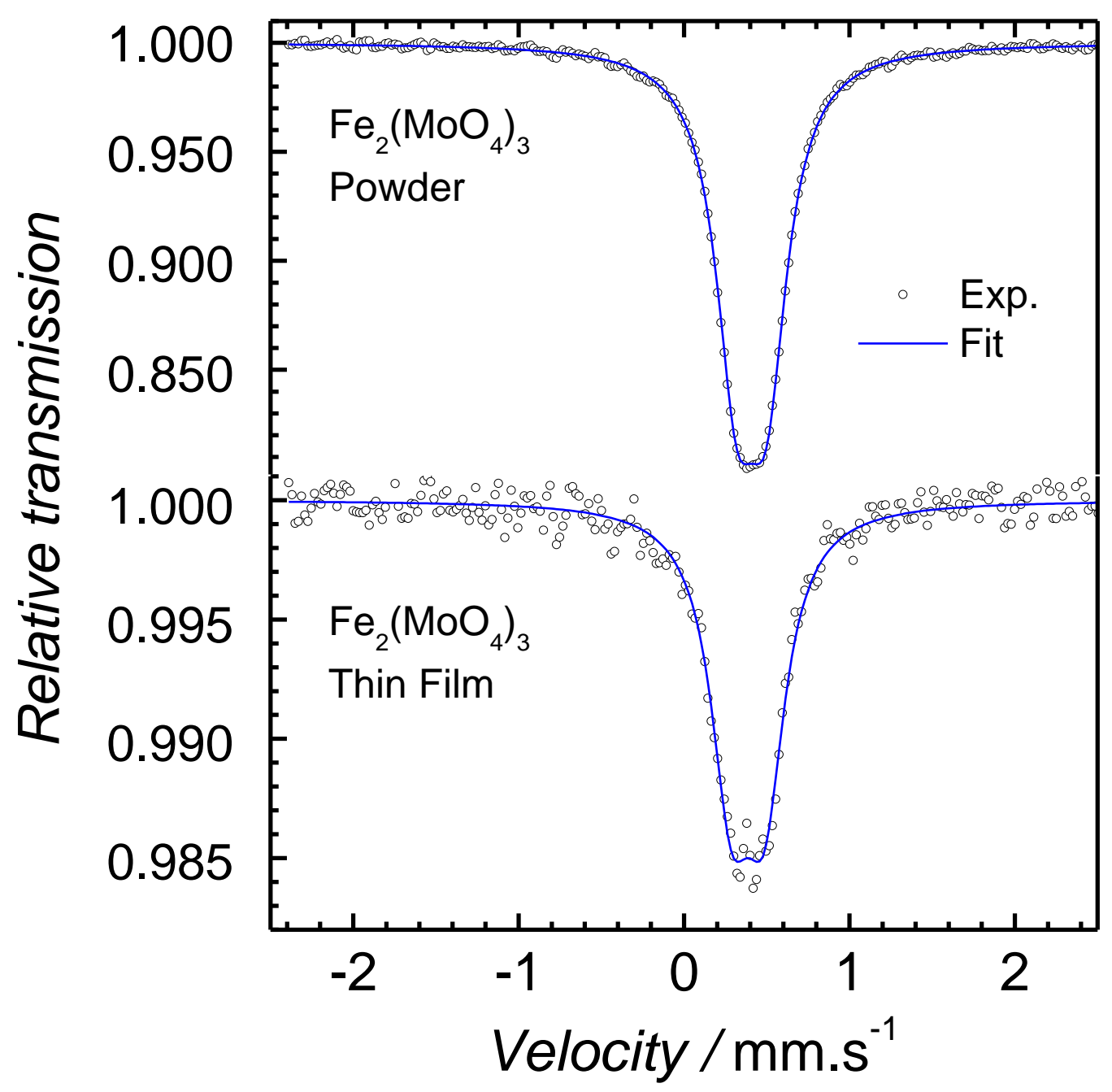


Figure 4

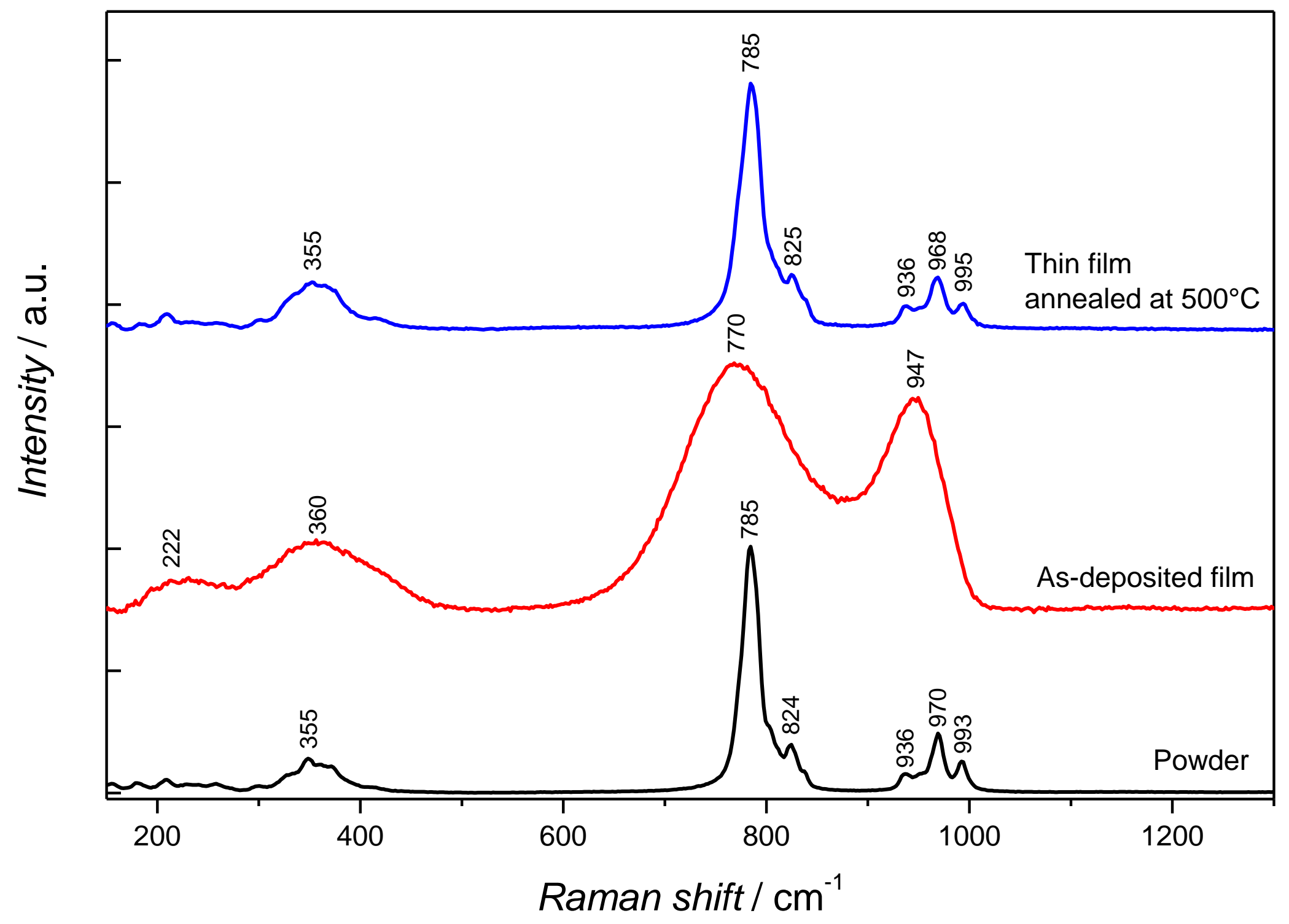


Figure 5
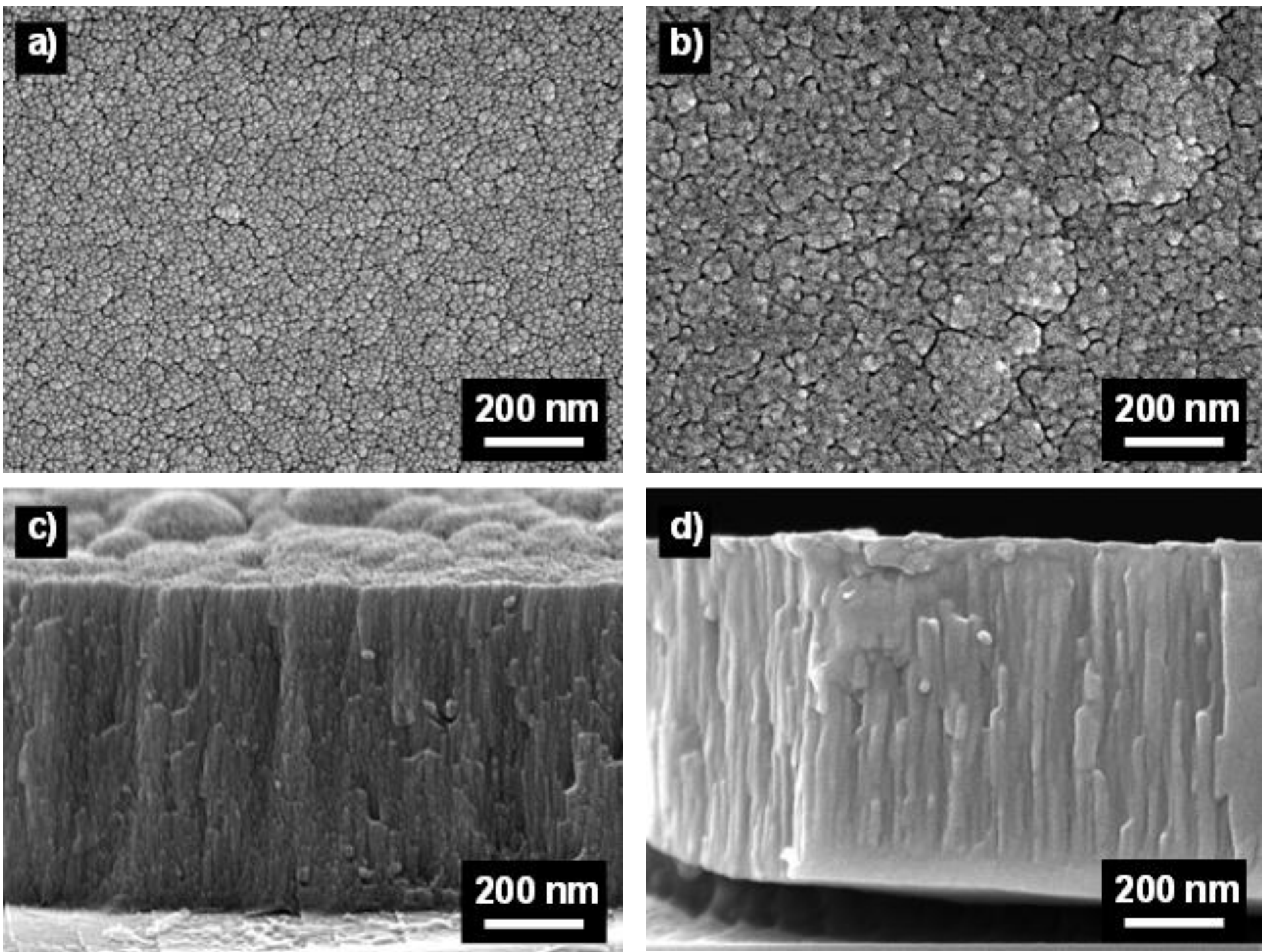
Figure 6
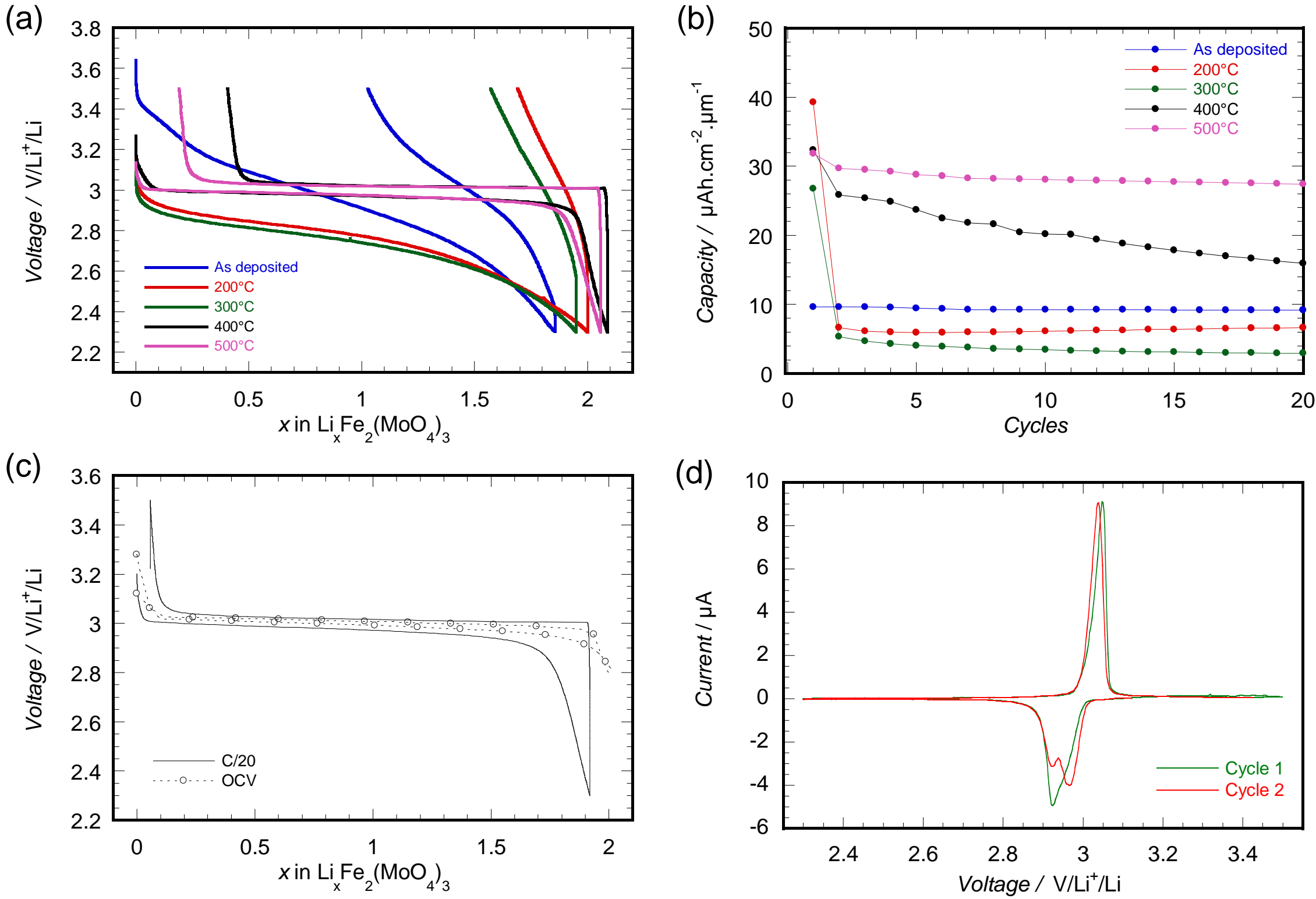


\section{Figure 7}

(a)

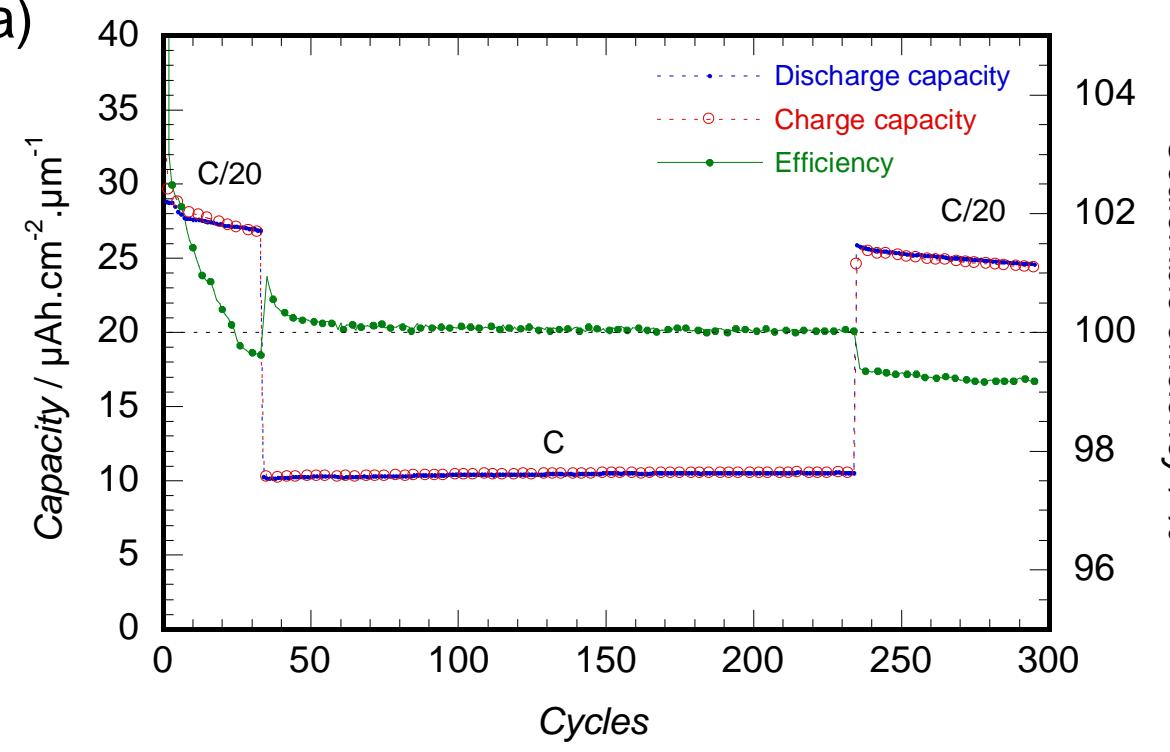

(b)

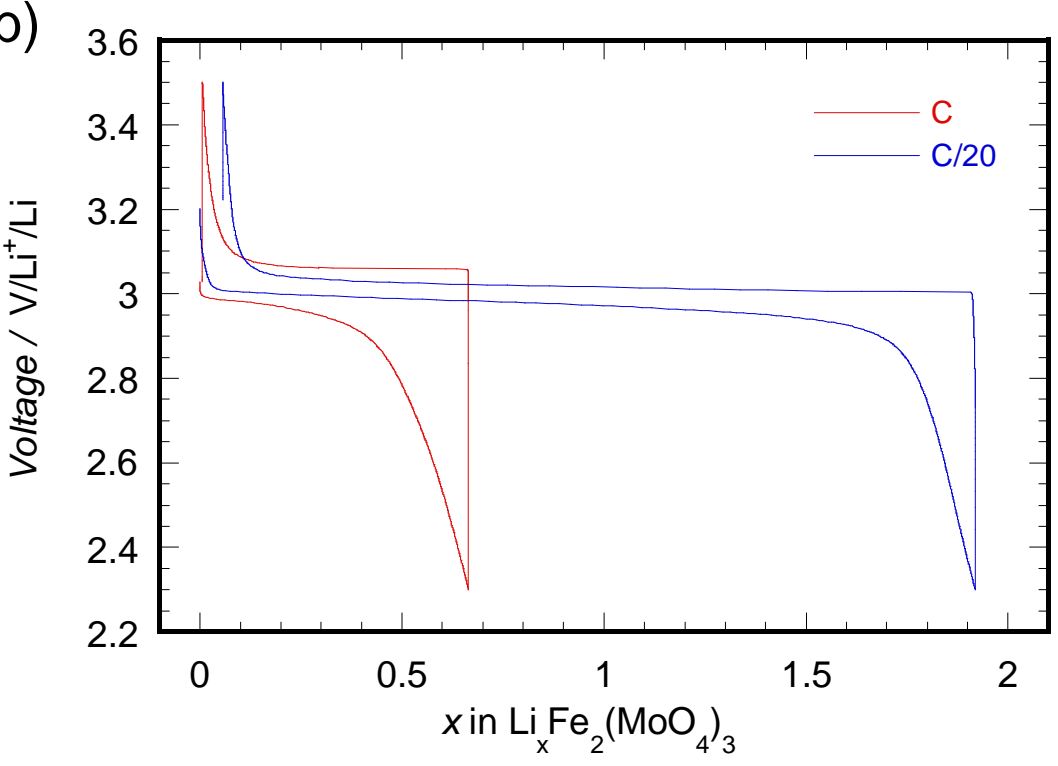

